\title{
Occupancy of young-of-year Arctic grayling (Thymallus arcticus) in Barrenland streams
}

\author{
Jared R. Ellenor (D) Peter A. Cott · Heidi K. Swanson
}

Received: 10 May 2021 /Revised: 21 October 2021/Accepted: 23 October 2021/Published online: 15 November 2021

(C) The Author(s) 2021

\begin{abstract}
Arctic grayling (Thymallus arcticus) is an iconic fish species that is present across the remote subarctic Barrenlands, yet our lack of understanding of their distributional patterns constrains predictions of anthropogenic effects on Barrenland populations. These adfluvial fish rely on seasonal lake-stream connections to migrate, spawn, and rear. We address knowledge gaps on what Barrenland stream attributes are suitable for rearing young-of-year Arctic grayling. Visual surveys of young-of-year Arctic grayling were conducted in 48 streams near Baker Lake, Nunavut, Canada. Occupancy modeling was used to relate stream habitat and landscape variables to fish presence/absence. The best predictors of occupancy were total area of contributing upstream lakes and landcover (upland/lowland); stream basins with larger contributing upstream lake area and more lowland
\end{abstract}

Handling editor: Pauliina Louhi

Supplementary Information The online version contains supplementary material available at https://doi.org/10.1007/ s10750-021-04742-3.

J. R. Ellenor $(\bowtie) \cdot$ P. A. Cott · H. K. Swanson

Department of Biology and Water Institute, University of

Waterloo, 200 University Avenue West, Waterloo,

ON N2L 3G1, Canada

e-mail: jared.ellenor@gmail.com

P. A. Cott

Cott Environmental, 540949 St., Yellowknife,

NT X1A 1R2, Canada cover were more likely to be occupied. Results suggest that occupancy reflects reliability of stream connectivity throughout the open water season and across years. The occupancy model developed here can adequately predict stream suitability for young-ofyear Arctic grayling using lake area and land classification data that are remotely accessed. This may lessen the considerable financial and logistical constraints of conducting field research on Arctic grayling in the vast Barrenlands and facilitate more directed field programs to inform conservation and mitigation plans.

Keywords Arctic grayling - Barrenland tundra . Stream habitat $\cdot$ Occupancy models

\section{Introduction}

Basic knowledge of life history and habitat requirements are lacking for many fish species in northern regions, which makes it difficult to develop effective conservation policies, avoid or mitigate potential climate- or development-related impacts, and direct restoration efforts (Jones et al., 2017). Arctic grayling [Thymallus arcticus (Pallas, 1776)], is a colourful, iconic salmonid with a Holarctic distribution (Scott \& Crossman, 1973). Valued by many stakeholders, including sport fishers (Scott \& Crossman, 1973; 
Read \& Roberge, 1984) and Indigenous communities (e.g., Kitikmeot Inuit Association, 2006), Arctic grayling is often a focal species in northern research studies and in environmental impact statements. In Arctic Barrenland landscapes, Arctic grayling often adopt a migratory adfluvial life history (e.g., Jones et al., 2003a, b; Baker et al., 2017), which makes them susceptible to habitat fragmentation and alterations in hydrologic flow and connectivity (Carl et al., 1992; Northcote, 1995). They also have low tolerance to increases in turbidity (Birtwell et al., 1984) and changes in water temperature (Haugen \& Vollestad, 2000), which makes them useful as a sentinel species (e.g., McLeay et al., 1987; Reynolds et al., 1989; Phibbs et al., 2011; Veldhoen et al., 2014). Despite their vulnerability, there is a distinct paucity of data for this species, particularly in more remote parts of their range. The resulting critical knowledge gaps regarding ecology and life history of Arctic grayling preclude accurate or precise predictions regarding potential impacts of human-induced stressors, particularly in regions where habitat use is poorly understood, such as in the Canadian Barrenlands.

In the Barrenlands, life history and habitat use of Arctic grayling are influenced by the unique geomorphology and climate of the region. The Barrenlands are a vast tundra plain (estimated at over 700,000 $\mathrm{km}^{2}$ ), stretching from Great Slave and Great Bear lakes in the Northwest Territories to the western coast of Hudson Bay in Nunavut, and are characterized by low elevation gradients, continuous permafrost, and abundant shallow lakes that are poorly integrated into large drainage systems (Baki et al., 2012). Many of the aquatic ecosystems in the Barrenlands are described as 'chain-lake systems', where streams can be thought of as short chains (a few hundred meters to a few kilometers) that provide critically important connections between lakes (Jones et al., 2003a). Adfluvial populations of Arctic grayling rely on the seasonally connected networks of lakes and streams to migrate, spawn, and rear (Jones \& Tonn, 2004; Baker et al., 2017). Lakes, which provide foraging habitat for adults as well as overwintering habitat for all life stages, become disconnected in winter, when streams are frozen to the bottom (winter can last more than 8 months on the Barrenlands) (Jones et al., 2003a; Baki et al., 2012). During spring freshet, the rapidly melting snowpack recharges lake basins and reconnects lakestream-river complexes, and adult adfluvial Arctic grayling out-migrate from lakes to spawning habitats in streams (Jones et al., 2003a). Adults typically migrate back to lakes shortly after spawning, before evaporation-induced declines in discharge affect connectivity for larger fish (Jones et al., 2003a). Youngof-year remain in streams to rear and feed throughout summer (Jones et al., 2003b, 2009; Baki et al., 2012), and must migrate from streams to lakes prior to freezeup in fall (Jones et al., 2003b). Slow decreases in lake water levels and stream discharge throughout summer can lead to discontinuous or dry stream channels (Jones et al., 2003a; Woo \& Mielko, 2007; Baki et al., 2012), and seasonal conditions can thus limit availability of suitable rearing habitat for YOY in natal streams. Understanding conditions and characteristics of Barrenland streams that support rearing YOY is critical for predicting recruitment, and can facilitate sound management of Arctic grayling in the Barrenlands.

Barrenland streams have diverse physical characteristics (Jones et al., 2003a), yet data on stream habitat preferences of Arctic grayling in this region are limited. To date, two studies have assessed habitat use of YOY Arctic grayling in Barrenland streams (Jones $\&$ Tonn, 2004; Baker et al., 2017). The authors of these studies found that water depth, water velocity, discharge, substrate, slope, amount of detritus, and cover by instream and overhanging vegetation affected presence of YOY Arctic grayling. The spatial scale investigated to date [approximately $120 \mathrm{~km}^{2}$ and a total of 20 streams across four drainage basins in NWT, Jones \& Tonn (2004) and Baker et al. (2017)], is small, and thus the full range of stream habitat conditions present in the Barrenlands was not fully represented. Additionally, studies to date have not quantified the influence of larger-scale landscape variables on habitat use by YOY Arctic grayling within streams. Regional factors, including variables that reflect climate, geology, and hydrology at scales larger than individual streams, are known to influence fish species composition and abundance (Hershey et al., 2006; Haynes et al., 2014; Laske et al., 2016), and effects of these factors on distributional patterns of Arctic grayling deserve further study.

The influence of geomorphic features on dispersal and habitat use of Arctic grayling has generally focused on occupancy in tundra lakes in Alaska (e.g., Hershey et al., 1999, 2006); streams have been less studied. Streams in the Barrenlands are largely 
colluvial, which means that fluvial processes are relatively ineffective at moving material and affecting channel morphology (Jones \& Tonn, 2004), and attributes such as substrate and geomorphology reflect the immediate surrounding landscape. Soil characteristics and moisture regimes range from hydric graminoid peat, to mesic shrub tundra and xeric boulder lichen tundra (Campbell et al., 2012), which affect stream conditions. Wet and poorly drained landscapes may promote hydrologic connectivity and allow stream flows to persist through summer, whereas well-drained boulder fields can result in isolation of streams or subsurface stream flow. This is most prevalent in late summer, when water levels are lower (Jones et al., 2003a; Courtice et al., 2014). In a region where summer evaporation typically exceeds precipitation, landscape factors that affect stream connectivity, such as size and composition of contributing catchments, have the potential to influence suitability and habitat use for YOY Arctic grayling.

Networks of connected lakes and streams typically cover more than $20 \%$ of the Barrenlands (see Jones et al., 2003a; Campbell et al., 2012), and the importance of considering how stream-lake connectivity influences abundance and distribution of fish species is becoming increasingly evident (e.g., Jones, 2010; Haynes et al., 2014; Laske et al., 2016; Pépino et al., 2017; Heim et al., 2019a). Water stored in lakes can stabilize the flow regime of outlet streams (Dorava \& Milner, 2000; Jones, 2010), with larger upstream lakes providing a source of water that may sustain flow throughout the summer (Jones et al., 2003a; Jones, 2010). Nearly all streams in the Barrenlands originate as lake outlets (Jones et al., 2003a), and as such the position of streams within Barrenland chainlake systems determines the potential for upstream lakes to act as stable and moderating sources of flow, which could in turn influence habitat suitability for YOY Arctic grayling.

The objective of the study was to relate occupancy of YOY Arctic grayling to a range of variables that represent both instream and landscape-level conditions of streams near the Hamlet of Baker Lake, in the Kivalliq region of Nunavut. Using a single-season, spatially replicated occupancy modelling approach, we aimed to identify variables that were best associated with occupancy of YOY Arctic grayling. The overarching goal of this work is to generate a more comprehensive understanding of the distribution of Arctic grayling in Barrenland streams.

\section{Methods}

Study area

Located within the vast, remote ecoregion of the Wager Bay Plateau Barrenland tundra, the study area (approximately $1,400 \mathrm{~km}^{2}$ ), extends north from the Hamlet of Baker Lake, Nunavut $\left(64.3176^{\circ} \mathrm{N}\right.$, $96.0220^{\circ} \mathrm{W}$ ) along a $175 \mathrm{~km}$ all-weather access road that services two gold mines, Meadowbank and Amaruq (Fig. 1). Access to this region is by air or sea only; there are no road connections other than between the hamlet and two mine sites located north of the hamlet. The study region is characterized by long, cold, dry winters $\left(-31.3^{\circ} \mathrm{C}\right.$ daily average temperature, $6.2 \mathrm{~mm}$ of precipitation in January), cool summers $\left(11.6^{\circ} \mathrm{C}\right.$ daily average temperature in July), and relatively wet autumns $(50.2 \mathrm{~mm}$ and $48.7 \mathrm{~mm}$ of precipitation in August and September, respectively) (Environment and Climate Change Canada, 2018). Study streams were limited to those that were accessible by foot (to a maximum distance of approximately $5 \mathrm{~km}$ ) from either the all-weather access road or roads within the Hamlet of Baker Lake. Study streams were located within three watersheds: two watersheds are within the Hudson Bay drainage basin, and one is located within the Arctic Ocean drainage basin (Fig. 1). Arctic grayling, lake trout [Salvelinus namaycush (Walbaum, 1792)], Arctic char [Salvelinus alpinus (Linnaeus, 1758)], round whitefish [Prosopium cylindraceum (Pennant, 1784)], cisco [Coregonus artedii (Lesueur, 1818)], burbot [Lota lota (Linnaeus, 1758)], ninespine stickleback [Pungitius pungitius (Linnaeus, 1758)], and slimy sculpin [Cottus cognatus (Richardson, 1836)] are present within the study area; however, species assemblages vary among lake/chain-lake complexes (C. Portt and Associates, 2018; J. Ellenor, unpublished data). Robust data on the use of seasonally available stream habitat are lacking. Where present, YOY Arctic grayling are the dominant species within streams, with occasional presence of ninespine stickleback, slimy sculpin, and juvenile salmonids (including grayling) (Cumberland Resources Ltd., 2005; J. Ellenor, unpublished data). 


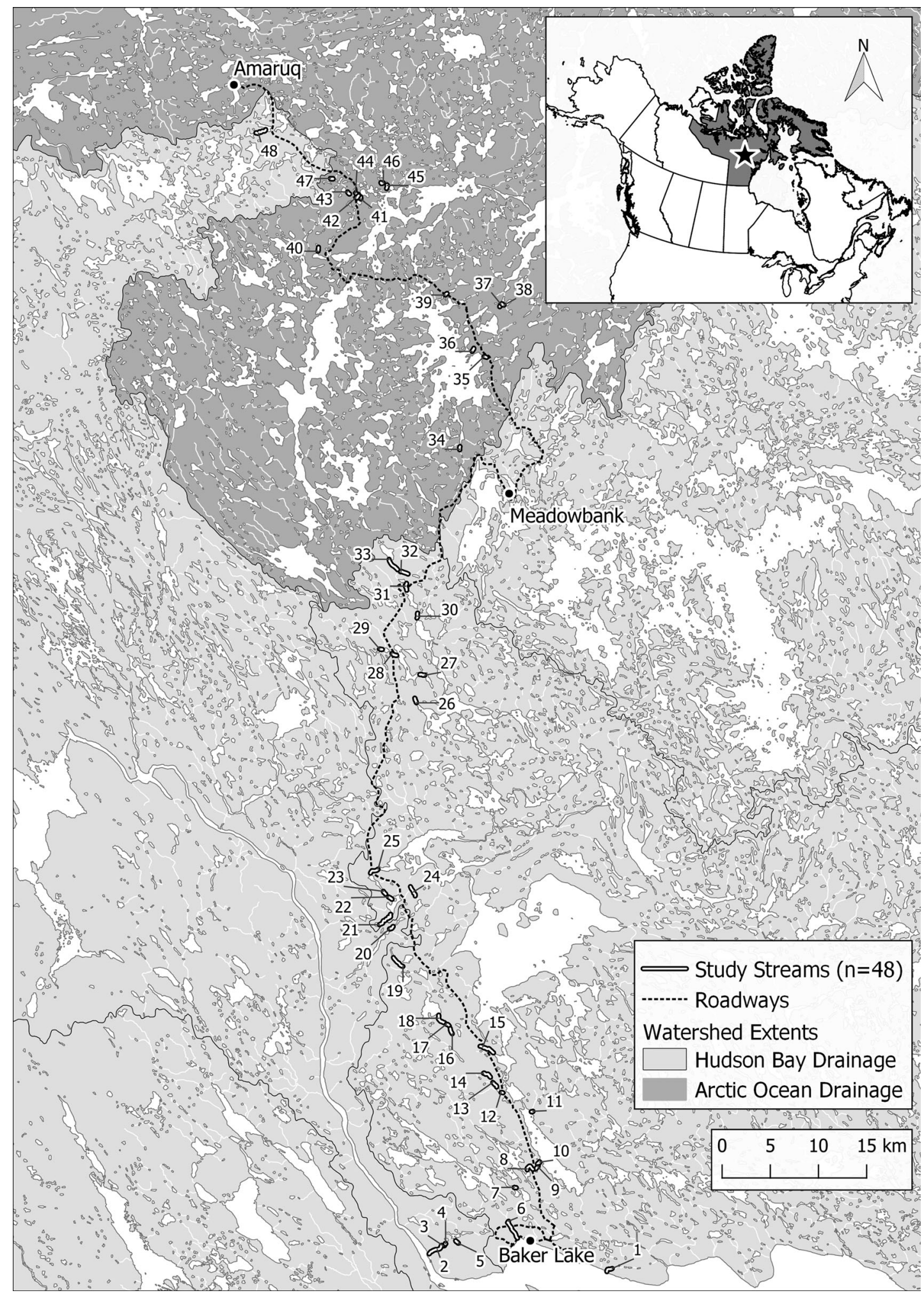


4 Fig. 1 Map of the study area, with watersheds delineated. The 48 study streams (identified numerically) were selected randomly from 109 candidate streams that were accessible by foot (within $5 \mathrm{~km}$ ) from all-weather roads. In the inset map, the territory of Nunavut is shaded in grey, and the star indicates the approximate location of the hamlet of Baker Lake, Nunavut, Canada and the mine sites of Meadowbank and Amaruq

Ecological land classification data exist for the region (Campbell et al., 2012). The twelve land classes present within the study area are defined by moisture and substrate, and range from moist, organic, graminoid tundra to dry, lichen-rock complexes (Fig. 2a). Logistical constraints on field sampling limited replication within land classes. Therefore, the twelve land classes were reduced to two land classes: (1) upland; and, (2) lowland (Fig. 2b). The 'lowland' land class includes poorly drained substrate dominated by organic materials, whereas the 'upland' land class includes well-drained inorganic substrates, such as gravel, boulder, and bedrock (Fig. S1).

\section{General study design}

A spatially replicated, single-season occupancy design was implemented to assess the probability that study streams were occupied by YOY Arctic grayling during the 2019 summer rearing period. Forty-eight streams were randomly selected from one-hundred and nine candidate streams within the study area. Candidate streams were identified using watershed shapefiles (Natural Resources Canada, 2016) and satellite imagery [either publicly available (Google Earth, 2019a, b, c) or supplied by Agnico Eagle Mines Ltd.]. Study streams ranged in length from $158 \mathrm{~m}$ to 2,268 m, with a median length of $461 \mathrm{~m}$. A sample site was randomly selected within each study stream. Sample sites were defined as five sequential $30 \mathrm{~m}$ surveys (spatial replicates), resulting in a total assessed length of $150 \mathrm{~m}$ per site (and therefore per stream). For each spatial replicate, presence or absence of YOY Arctic grayling was assessed and covariate data (e.g., habitat, sampling conditions) were collected.

Presence or absence of YOY Arctic grayling was assessed using streamside visual surveys, which have been shown to be an effective and efficient technique in Barrenland streams (Baker et al., 2017). False detections of YOY Arctic grayling during visual surveys were unlikely, as Arctic grayling is the only salmonid present within the study area that spawns in the spring, and the only salmonid known to spawn and rear in Barrenland streams. YOY Arctic grayling also occupy a unique size class relative to other juvenile salmonids. They are also distinguishable from smallbodied fish species, such as ninespine stickleback and slimy sculpin, based on their size, body shape, and behaviour. Prior to the onset of the formal study, trial visual surveys of YOY Arctic grayling in study area streams was followed by capture of individuals to confirm identification, and revealed consistent positive identification of YOY Arctic grayling.

Surveys were completed from July 16 to August 7, 2019. Survey dates were selected based on the observed timing of spawning, egg incubation, and YOY rearing in streams within the study area during summer 2018 (J. Ellenor, unpublished data). Consistent with the assumption of closure in occupancy modeling, the survey dates also reflect a period when YOY Arctic grayling have previously been observed rearing in Barrenland streams (Jones et al., 2003a; Artym, 2016), and several weeks in advance of migration to overwintering lakes, which typically occurs just prior to freeze-up (Jones et al., 2003b; Driedger et al., 2011).

During visual presence/absence surveys, two surveyors started on opposite ends of the most downstream replicate of a site. Surveyors walked towards each other along the stream bank while visually searching for YOY Arctic grayling. There were no restrictions placed on search method, and each team member was free to move about the replicate as they deemed fit. This included potentially entering the stream, a method that was typically only employed when stream width prevented effective visual surveys of the entire channel from the bank. After $3 \mathrm{~min}$ had elapsed, surveyors paused to confirm if either had a positive detection. If both had observed YOY Arctic grayling, the survey was deemed complete. If only one observer, or neither observer, had observed YOY, the survey continued until $8 \mathrm{~min}$ had elapsed, at which point the survey was considered complete, regardless of detection. A maximum survey duration of $8 \mathrm{~min}$ provided sufficient time to effectively search a $30 \mathrm{~m}$ segment of stream. The process was then repeated at adjacent upstream replicates. The same two team members conducted all surveys in 2019 . 

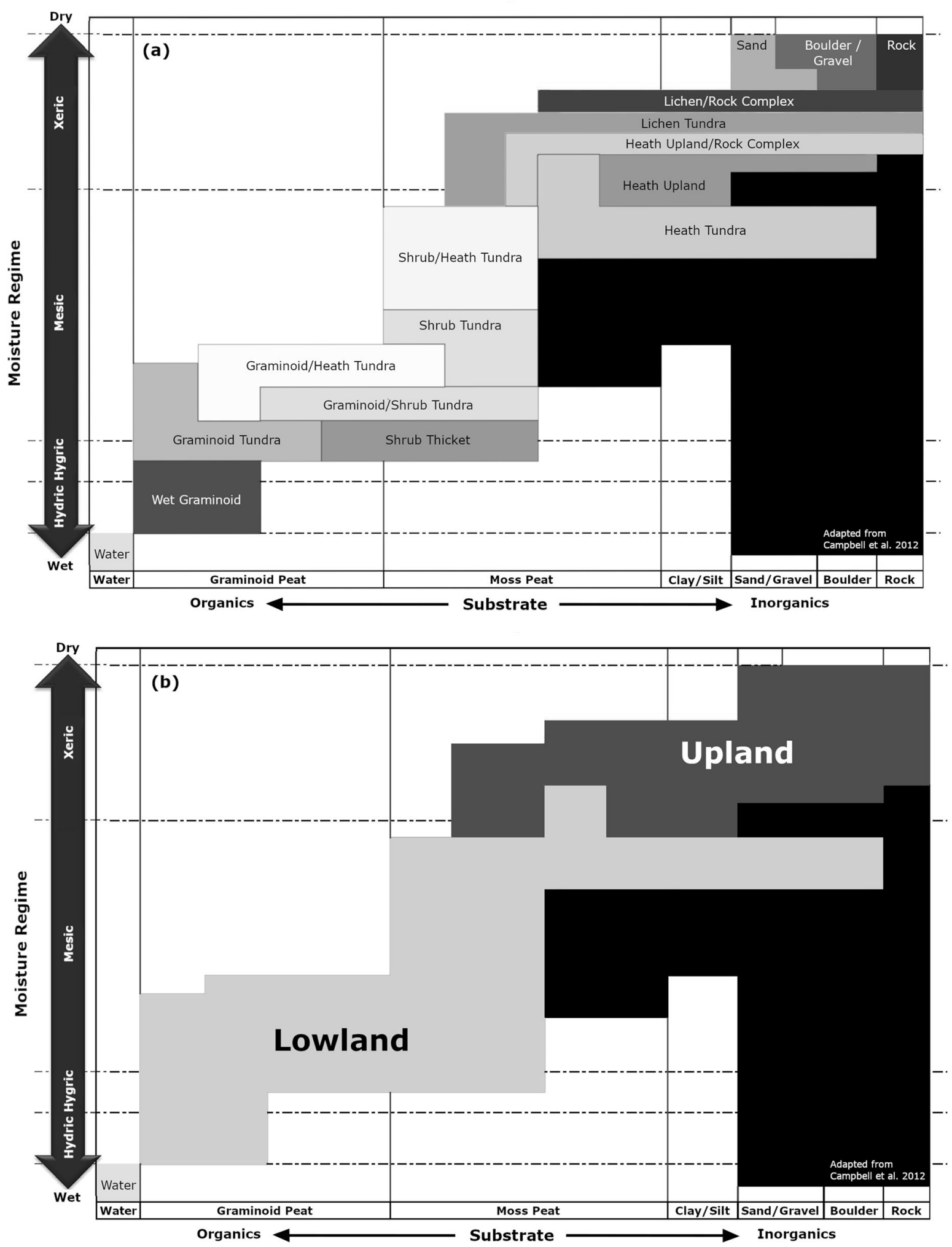
4Fig. 2 Moisture regime and substrate characteristics for a twelve ecological land cover classes identified in Campbell et al. (2012) and b simplified lowland and upland land cover classes. The delineation of lowland and upland classes for this study was based on moisture. Moist vegetation classes (i.e., mesic, hygric, and hydric) were classified as lowland, whereas dry vegetation classes (i.e., xeric) were classified as upland. Images adapted with permission

The probability of detecting Arctic grayling in a replicate, given presence, was anticipated to be influenced by instream (e.g., water depth, substrate, stream width) and other environmental (e.g., percentage of sunlight/cloud cover during the survey) variables. Similarly, stream habitat and/or landscape level variables were expected to influence the probability of occupancy; the relationship between these variables and probability of occupancy was the primary focus of this study. To account for heterogeneity in probability of detection and occupancy, covariate data were collected and incorporated into candidate models (Table 1). Consistent with established approaches (e.g., MacKenzie et al., 2018), variables thought only to influence probability of detection were collected at each spatial replicate (site), whereas variables thought to influence the probability of occupancy were collected at each stream. Variables that were thought to influence both probability of detection and probability of occupancy that are likely to vary by replicate (e.g., water velocity) were collected at the scale of $30 \mathrm{~m}$ replicates to model probability of detection, and then averaged (arithmetic mean) across all replicates to model probability of occupancy.

Depth and velocity measurements were collected using a topset rod mounted to a HACH FH950 handheld flowmeter (HACH, Loveland, CO). Readings were taken at five points per $30 \mathrm{~m}$ replicate along a transect that ran perpendicular to the stream flow. Transect and measurement locations were selected to capture representative depth/velocity conditions. This

Table 1 Summary of covariates, including collection methods, that were collected to account for potential heterogeneity in probability of detection (30 $\mathrm{m}$ replicate; site) and probability of occupancy (stream)

\begin{tabular}{|c|c|c|c|}
\hline Probability affected & Collection scale & Covariate & Collection method \\
\hline \multirow[t]{5}{*}{ Detection } & \multirow[t]{5}{*}{$30 \mathrm{~m}$ Replicate } & Survey date & - \\
\hline & & Time of day & - \\
\hline & & Survey technician & - \\
\hline & & Cloud cover & Visual estimate $(\%)$ \\
\hline & & Precipitation & Type/intensity category \\
\hline \multirow[t]{16}{*}{ Detection and occupancy } & \multirow[t]{9}{*}{$30 \mathrm{~m}$ Replicate } & Depth & Wading rod (m) \\
\hline & & Velocity & Flow meter $(\mathrm{m} / \mathrm{s})$ \\
\hline & & Substrate & Estimate (\%, per size class) \\
\hline & & Instream vegetation & Estimate $(\%)$ \\
\hline & & Overhanging vegetation & Estimate $(\%)$ \\
\hline & & Undercut bank & Estimate $(\%)$ \\
\hline & & Wetted width & Tape measure/range finder (m) \\
\hline & & Number of channels/braids & Count \\
\hline & & Slope & Inclinometer $(\%)$ \\
\hline & \multirow[t]{7}{*}{ Stream } & Discharge & Flow meter $\left(\mathrm{m}^{3} / \mathrm{s}\right)$ \\
\hline & & Stream temperature & Temperature logger $\left({ }^{\circ} \mathrm{C}\right)$ \\
\hline & & $\mathrm{pH}$ & In situ meter \\
\hline & & Dissolved oxygen & In situ meter ( $\mathrm{mg} / \mathrm{L}, \%$ saturation) \\
\hline & & Specific conductivity & In situ meter $(\mu \mathrm{S} / \mathrm{cm})$ \\
\hline & & Land classification & GIS \\
\hline & & Cumulative upstream lake area & GIS \\
\hline
\end{tabular}


transect was also used to measure total stream width (wetted edge to wetted edge, while removing the width of any mid-channel bars). Locations selected for discharge measurements had laminar flow that was perpendicular to the streambank. Discharge readings followed methods outlined by the Water Survey of Canada (Lane, 1999).

Water temperature data were collected at each stream using a single TidbiT ${ }^{\circledR}$ V2 temperature logger set to record at 10-min intervals (Onset Computer Corporation, Bourne, MA). Each temperature logger was placed in a solar shield, attached to a weight, and placed at the bottom of the stream. Temperature data are available for all streams from June 27, 2019 to August 29, 2019. Summary statistics were calculated for each stream, including daily mean, mean minimum, mean maximum, and mean daily coefficient of variation (CV), as well as accumulated thermal units (ATU). Temperature data preparation and analysis were completed in R (R Core Team, 2019).

In situ water quality data were collected using calibrated hand-held meters. Dissolved oxygen (mg/L and $\%$ saturation) data were collected using an OxyGuard Handy Polaris (OxyGaurd International A/S, Farum, Denmark). Specific conductivity $(\mu \mathrm{S} / \mathrm{cm})$ and $\mathrm{pH}$ data were collected using a YSI Pro Plus (YSI Incorporated, Yellow Springs, OH). Meters were allowed sufficient time to equilibrate in the stream prior to recording measurements.

Substrate was estimated visually, and recorded as relative percentages of streambed material. Streambed material was categorized as organic material, or size class of inorganic material [bedrock, boulder, cobble, etc.; (Bain et al., 1985)]. In-stream vegetation was estimated visually as the percentage of in-stream cover provided by emergent/submerged vegetation, whereas overhanging vegetation was estimated visually as the percentage of the streambank with overhanging vegetation. Stream slope was calculated using an inclinometer along a straight portion of stream that had representative slope.

Ecological land classification data for the study area were provided as a raster dataset $(25 \mathrm{~m} \times 25 \mathrm{~m}$ resolution) by the Nunavut Department of Environment and Caslys Consulting (Campbell et al., 2012), imported into QGIS (QGIS Development Team, 2020), and simplified into two classes (Fig. 2). Study streams were digitized as linear segments, and a $10 \mathrm{~m}$ buffer (total width of $20 \mathrm{~m}$ ) was applied to each stream. Percentages of upland and lowland land classes within the buffer areas were then calculated for each stream.

Lake polygon and watercourse data used to calculate the surface area of contributing upstream lakes were obtained from the National Hydro Network (Natural Resources Canada, 2016). Surface areas of lakes within the study region were calculated using QGIS (QGIS Development Team, 2020). The contributing upstream lake surface area for each stream was calculated as the sum of all upstream lake surface areas (i.e., surface area of all upstream lakes that are connected by a watercourse, as identified by the National Hydrology Network shapefile).

Statistical analysis

$\mathrm{R}$ version 3.6.2 (R Core Team, 2019) was used for data visualization using packages ggplot2 (Wickham, 2016), see (Lüdecke et al., 2020), and patchwork (Lin Pederson, 2020). Construction of occupancy models was achieved using the RPresence package (MacKenzie \& Hines, 2019). Prior to the construction of occupancy models that incorporated covariates, a comparison was made between static single-season and single-season correlated detection null models as recommended by MacKenzie et al. (2018). This comparison assessed the need to account for autocorrelated data, which could occur if the presence/ absence of YOY in a downstream replicate was influenced by the presence/absence of YOY in the replicate immediately upstream.

The construction of single-season occupancy models was divided into two components: (1) modeling variables that affected the probability that YOY were present at a site (stream); and (2) modeling variables that affected the probability that YOY were detected at a $30 \mathrm{~m}$ replicate. While initially modeling for stream occupancy, the probability of detection was held constant at $\mathrm{p}(\cdot)$. Covariates of probability of detection were then incorporated into top candidate occupancy models.

Due to the small number of study streams $(n=48)$, a maximum of three occupancy covariates were included in any one a priori model to avoid overparameterization (Anderson, 2008). Data transformations for continuous occupancy covariates were assessed prior to model construction. A transformation was applied if the covariate clearly had a large 
influence on the probability of occupancy within a small range of its total observed range, and a reduced influence for the remainder of the observed range (see MacKenzie et al., 2018). Continuous covariates in detection and occupancy datasets were also standardized (z-score) prior to model construction and assessed for collinearity using Pearson correlation coefficients (pair-wise comparisons). Covariates with a correlation coefficient with an absolute value greater than 0.5 were not included in the same model.

Candidate models were assessed using Akaike's Information Criterion, incorporating an additional bias correction term (AICc) for small sample sizes (Anderson, 2008). Following Baker et al. (2017), the number of streams $(n=48)$ was selected as the 'effective' sample size for the AICc correction term. Constructed models were compared based on their relative difference in AICc values ( $\triangle \mathrm{AICc}$ ), model weights, and evidence ratios (Anderson, 2008). Model fit was assessed using the methods outlined in MacKenzie \& Bailey (2004). Pearson's chi-squared $\left(\chi^{2}\right)$ test statistics for observed and parametric bootstrapped data were compared to determine the probability of obtaining the observed detection history at each stream, assuming the model was correct (MacKenzie et al., 2018). Additionally, an independent test data set of seven streams located along the all-weather access road from Meadowbank to Amaruq (Fig. 1) were used to assess model fit. These streams were electrofished between 25 June and 02 September, 2014-2015, prior to road construction and prior to design and implementation of this study (C. Portt and Associates, 2015).

\section{Results}

Young-of-year Arctic grayling were detected in 32 of 48 surveyed streams, resulting in a naïve occupancy estimate of 0.67 (naïve occupancy assumes perfect detection). In the 32 streams occupied by YOY, they were detected in 130 of 160 replicates, resulting in an overall detection probability of 0.81 . YOY were detected in all five replicates (i.e., perfect detection) in twenty of the thirty-two occupied streams (63.5\%). They were detected in four of five replicates in two streams $(6.3 \%)$, in three of five replicates in four streams $(12.5 \%)$, in two of five replicates in four streams $(12.5 \%)$, and in one of five replicates in two streams (6.3\%) (Fig. S2).

\section{Occupancy}

\section{Type of occupancy model}

A correlated detection null model was run to assess the need to account for autocorrelated data (i.e., the presence/absence of YOY in a downstream replicate was influenced by the presence/absence of YOY in the replicate immediately upstream). The correlated detection null model failed to converge. Lack of convergence could mean that sequential spatial replicates were not correlated, or result from other factors, including: (i) an insufficient number of sites or replicates to accurately model autocorrelation; and/ or, (ii) an overall high detection rate, and a low number of sites with imperfect detection. In a similar study of YOY Arctic grayling occupancy in Barrenland streams, Baker et al. (2017) found clear evidence of spatial dependency with fewer sites and replicates (9 streams, 67 replicates), and a lower, more variable detection rate. In this study, the start location of a site was randomly selected in each stream, and the mean percentage of total stream length that was surveyed was 34\% (range of 7-96\%). A high overall detection probability $(0.81)$ and high percentage of sites with perfect detection (63.5\%), suggests that YOY were present throughout the occupied streams. Further, detection histories for the limited number of streams with imperfect detection showed no clear upstream to downstream relationship with presence/absence (Fig. S2). Given that occupancy was assessed at the stream level, it is anticipated that randomly selected replicates within a stream would produce similar results. Because the correlated detection model did not converge, all candidate models were constructed using the static single-season occupancy equation.

\section{Occupancy covariates}

Investigative plots revealed that several variables potentially influenced the probability of a stream being occupied by YOY Arctic grayling (Fig. 3): substrate, slope, water temperature, discharge, lowland cover, and contributing upstream lake area.

Most study streams were dominated by inorganic substrates, primarily boulder and/or cobble. No 
(a)

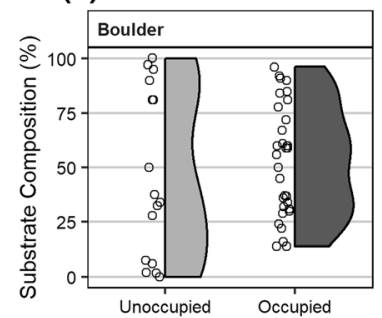

(b)

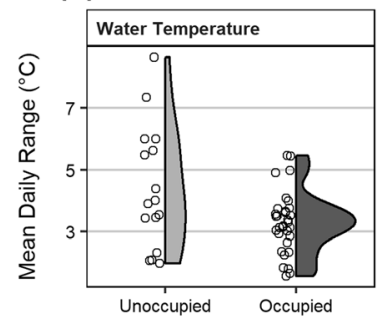

(f)

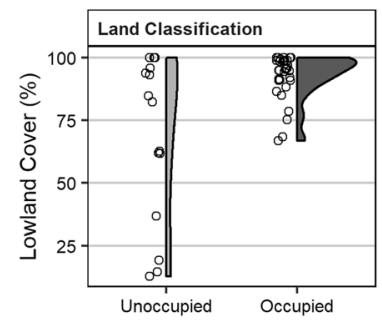

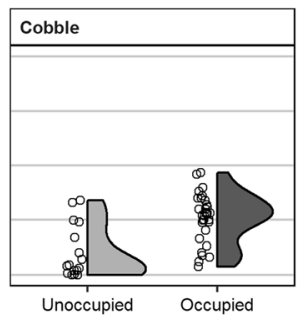

(c)

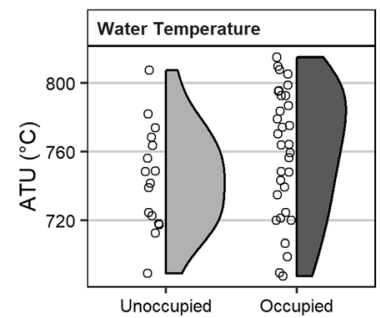

(g)

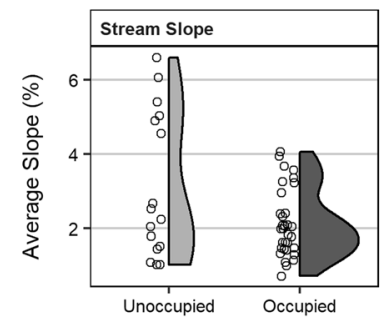

Fig. 3 Relationships between stream occupancy of young-ofyear Arctic grayling and select stream- and landscape-level covariates. Individual study streams are represented by open

individual size class (e.g., boulder, cobble, or gravel) of inorganic substrate was related to stream occupancy (Fig. 3a). The sum of all sizes classes of inorganic substrate [i.e., \% inorganic substrate (Fig. 3a)] was, however, positively and non-linearly related to occupancy. Increases in \% inorganic substrate had a greater effect on the probability of occupancy when \% inorganic substrate was low, and a lesser effect when $\%$ inorganic substrate was high (Fig. 3a).

The percentage of inorganic substrate was correlated with various water temperature covariates, suggesting that water temperature may also influence stream occupancy. There was a strong, negative correlation between $\%$ inorganic substrate and mean daily temperature range $(r=-0.74$; Fig. $3 b)$ and mean daily max temperature $(\mathrm{r}=-0.65)$ (Table $\mathrm{S} 1)$. Other temperature metrics, such as ATU, provided little explanation for the observed distribution of YOY among streams (Fig. 3c).
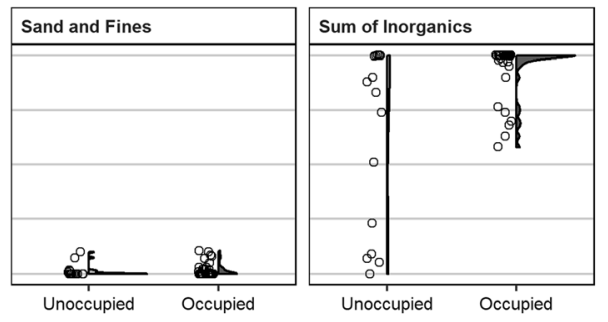

(d)

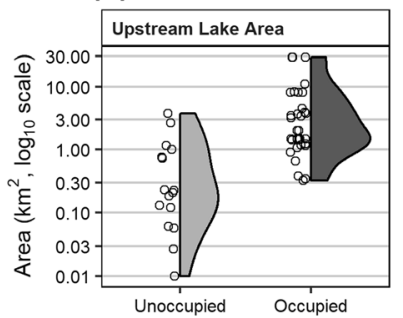

(h)

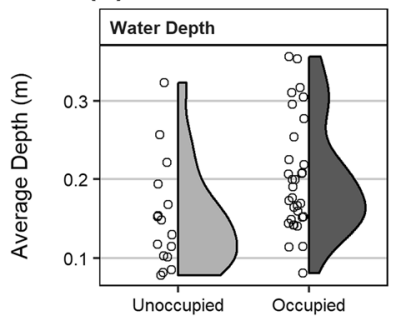

(e)

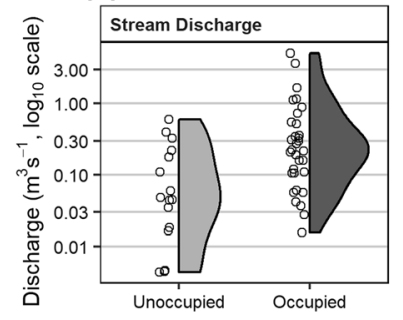

(i)

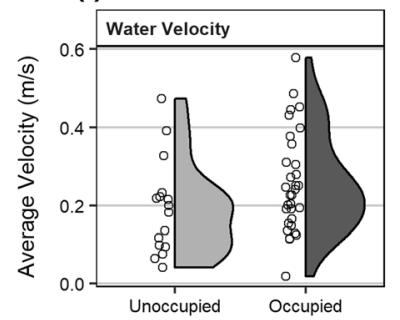

circles. Distribution curves for each covariate for occupied and unoccupied streams are kernel density estimations. Data were collected near Baker Lake, Nunavut, Canada in 2019

The cumulative surface area of lakes upstream varied considerably among study streams $\left(0.01 \mathrm{~km}^{2}-\right.$ $26.5 \mathrm{~km}^{2}$ ). YOY were not detected in any of the ten streams with upstream contributing lake area less than $0.3 \mathrm{~km}^{2}$ (Fig. 3d). The likelihood that a stream was occupied increased considerably when upstream contributing lake area exceeded $\sim 0.3 \mathrm{~km}^{2}$. Contributing upstream lake area was positively and significantly correlated with stream discharge $(r=0.87$, Table S1, Fig. S3). The pattern of stream occupancy for upstream lake area and discharge were nearly identical (Fig. 3d, e), suggesting that upstream lakes provide an important source of water for streams. Although not strongly correlated, many of the streams with low contributions of upstream lake area also had high \% organic substrate $(r=-0.28$, Table $\mathrm{S} 1)$, and the six streams with the highest $\%$ organic substrate all had contributing upstream lake areas $<0.33 \mathrm{~km}^{2}$. 
The dominant land cover for most study streams was lowland (i.e., moist, organic substrate). Of the 41 streams with $>65 \%$ lowland land cover, 32 (78\%) contained YOY. Streams with $<65 \%$ lowland land cover ( $\geq 35 \%$ upland land cover), did not contain YOY grayling (Fig. 3f). The relationship between YOY grayling occupancy and land classification was similar to the relationship between YOY grayling occupancy and substrate-small increases in \% lowland land cover had a greater effect on the probability of occupancy when \% lowland land cover was low to moderate (i.e., $<65 \%$ ) (Fig. 3f).

The average slope of surveyed streams varied from $0.7 \%$ to $6.6 \%$. YOY Arctic grayling were not detected in the six streams where average slopes exceeded $4.1 \%$ (Fig. 3g), suggesting that as stream slope increases, the probability that the stream is occupied decreases. YOY grayling were found within streams with a range of average depths, and velocities (Fig. 3h, i, Table S2), and these variables did not appear to be strong predictors of occupancy.

Occupancy model results

Covariates included in candidate models for occupancy were limited to five variables: \% lowland, $\%$ inorganic substrate, slope, mean daily water temperature range, and upstream lake area. A comparison of the $\Delta$ AICc values shows a clear top model (Table 2). Land classification (\% lowland) and contributing upstream lake area were the best predictors of occupancy of YOY Arctic grayling in streams. Regression coefficients (on the logit scale) show the magnitude and direction of the covariate on the probability of occupancy, $(\widehat{\psi})$ (MacKenzie et al., 2018). For the top model, this can be written as:

$$
\begin{aligned}
\operatorname{logit}(\widehat{\psi})= & \beta_{0}+\beta_{1} \times \sqrt{\text { Lowland } \%}+\beta_{2} \\
& \times \log _{10}(\text { UpstreamLakeArea })
\end{aligned}
$$

where $\beta$-coefficients (standard errors) are, $\beta_{0}=2.02$ (0.82), $\beta_{1}=1.97$ (0.74), and $\beta_{2}=4.10$ (1.44).

Estimates of $\beta$-coefficients indicated that increases in lowland land cover and increases in contributing upstream lake surface area both increased the probability that a stream was occupied by YOY Arctic grayling. Streams with larger contributing upstream lake area and more lowland cover were more likely to be occupied. Probability of occupancy was calculated for $\%$ lowland values ranging from $0 \%$ to $100 \%$, while contributing upstream lake area was held constant at the median observed value $\left(1.43 \mathrm{~km}^{2}\right)$ (Fig. $4 \mathrm{a}$ ). Streams surrounded exclusively by lowland land cover had a high likelihood of containing YOY grayling. The probably of occupancy decreased as lowland land cover decreased. Confidence intervals (95\% CI) around the probability of occupancy, calculated using the delta method (MacKenzie et al., 2018), indicated higher confidence in predicting occupancy at high percentages of lowland land cover (i.e., $>85 \%$ ) (Fig. 4a). When examining the relationship between contributing upstream lake area and occupancy [while holding \% lowland land cover constant at the median study stream value $(94.5 \%)]$, the probability that a stream was occupied increased sharply from 0 to 0.8 as contributing upstream lake area increased from $0 \mathrm{~km}^{2}$ to $1 \mathrm{~km}^{2}$ (Fig. $4 \mathrm{~b}$ ). As contributing upstream lake area increased beyond $1 \mathrm{~km}^{2}$, the $95 \%$ confidence interval narrowed, suggesting increasing confidence that a stream was occupied as upstream lake surface area increased.

Occupancy was highest when contributing upstream lake area and percent lowland land cover were both high (Fig. 5a). Some combinations of percent lowland land cover and contributing upstream lake area were not represented within the study. Given the random sampling design, it is likely these conditions are rare within the study area.

When the 16 unoccupied streams were examined, it was evident that absence of YOY Arctic grayling in 10 of these streams was explained by insufficient contributing upstream lake area (Fig. 5b). In four of the unoccupied streams, insufficient contributing upstream lake area did not appear to be an explanation. These four streams had the lowest percentages of lowland land cover of any of the study streams. These results suggest that streams located in landscapes with more uplands require more upstream lake area to be suitable for YOY. Absence of YOY Arctic grayling in two streams was not explained by either land cover or contributing upstream lake area (Fig. 5b).

The model predicted both presence and absence of YOY Arctic grayling with confidence (i.e., small confidence interval range) under certain combinations of upstream lake area and land cover (Fig. 5c). There was high confidence that streams with low $\%$ lowland land cover and small contributing upstream lake areas were unoccupied. Similarly, there was high confidence 


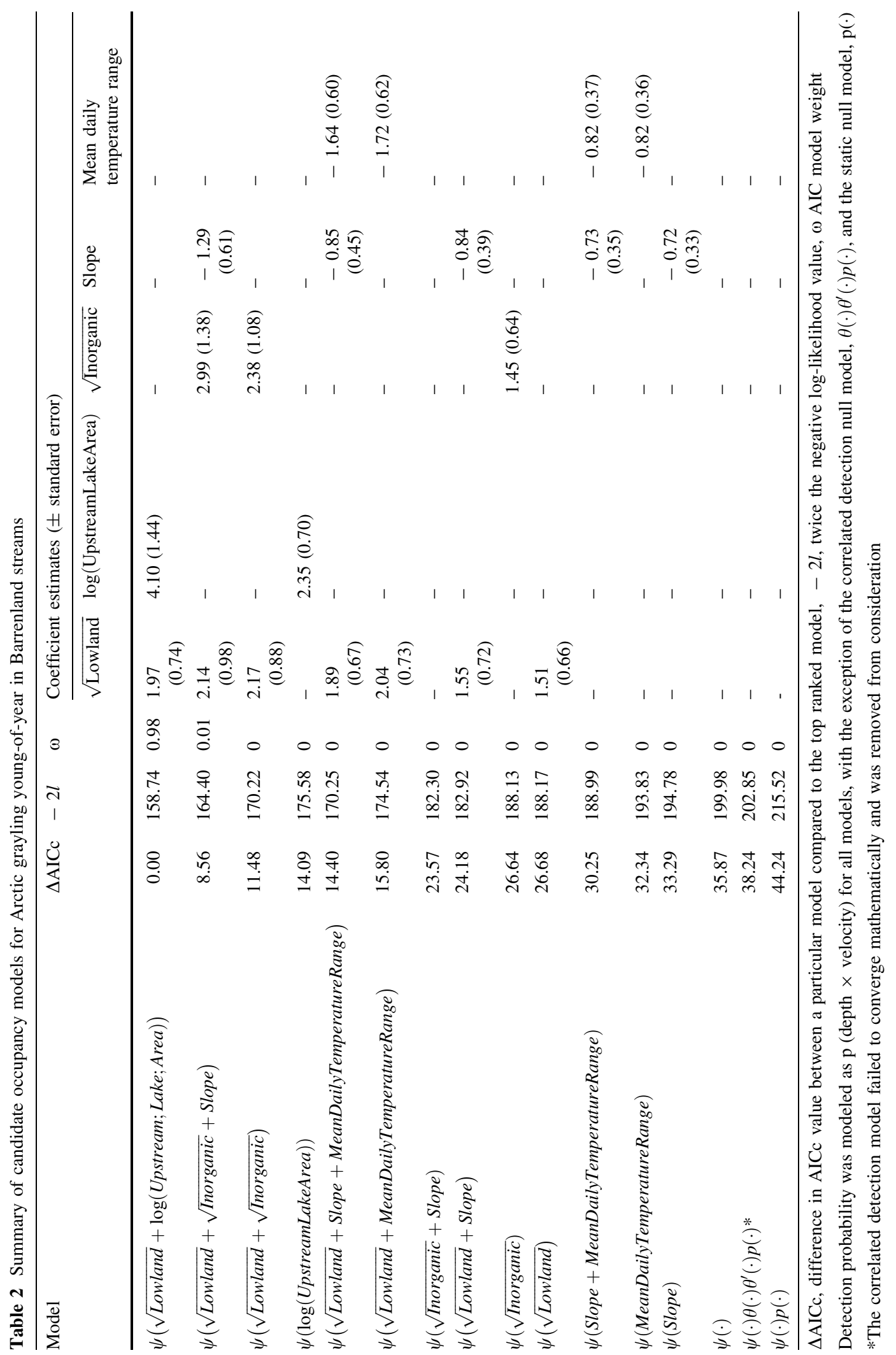


Fig. 4 Relationship between a probability of occupancy of young of year Arctic grayling and \% lowland land cover at the median value of contributing upstream lake $\left(1.43 \mathrm{~km}^{2}\right)$; and, b probability of occupancy and contributing upstream lake area at the median value of $\%$ lowland land cover (94.5\%). Vertical tick marks along the $\mathrm{x}$-axis are sampled stream values used to construct the model. Data were collected near Baker Lake, Nunavut, Canada in 2019 (a)

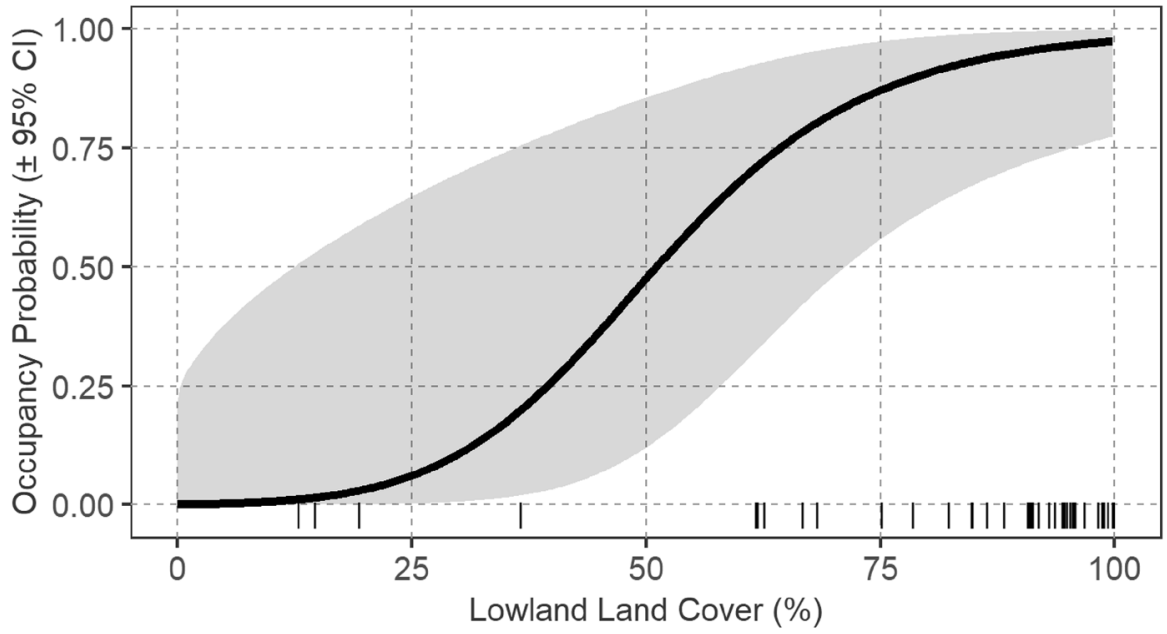

(b)

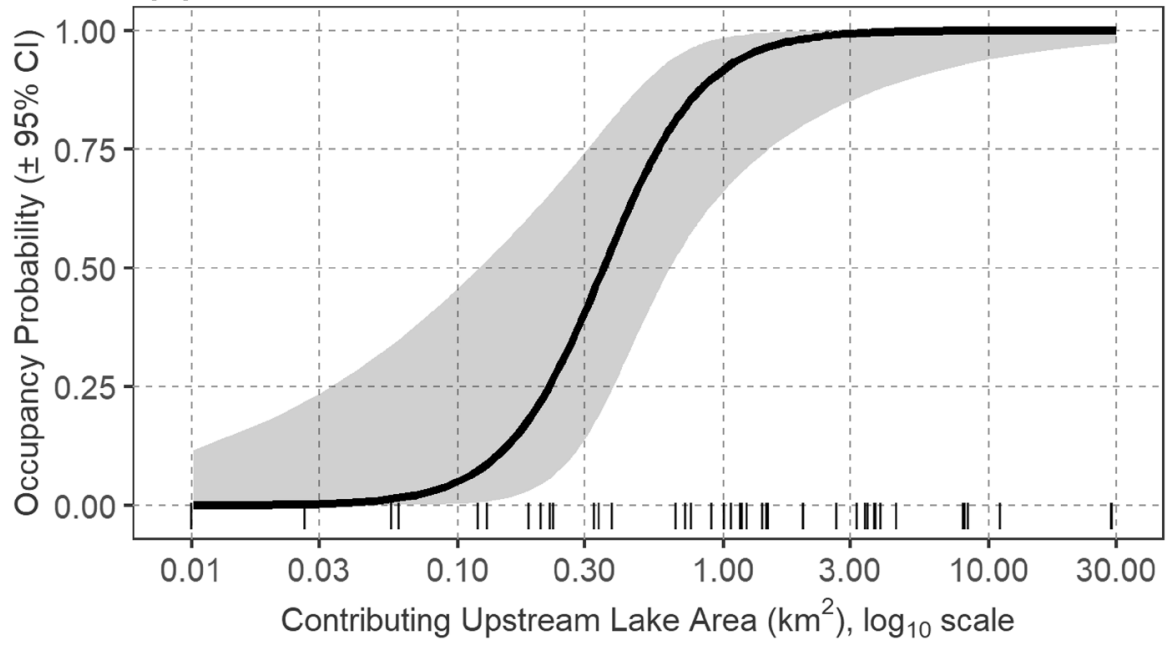

that streams with high \% lowland land cover and large contributing upstream lake areas were occupied (Fig. 5c). Uncertainty was greatest where the two covariates had an opposing influence on occupancy. For instance, if a stream with a low percentage of lowland land cover also had a large contributing upstream lake area, there was increased uncertainty in the model result (Fig. 5c). This was particularly true for conditions that were under-sampled (and/or less common) in the study area.

\section{Detection}

Each of the covariates for probability of detection was individually considered for inclusion in candidate models. A summary of the observed range of each variable, and the ranges of covariates for replicates where YOY Arctic grayling were and were not detected are provided in Table S3. Depth and velocity were the only two detection variables with a lower AICc score than the null model, indicating that depth and velocity provided some explanation for imperfect detection (Table 3). The highest ranked model included an interaction between depth and velocity, but there was also support for an additive model (Table 3). An examination of regression coefficients (Table 3) revealed that increases in depth and/or velocity decreased the likelihood of YOY being detected, which is intuitive given that surveys were conducted visually and fish are more difficult to see at 

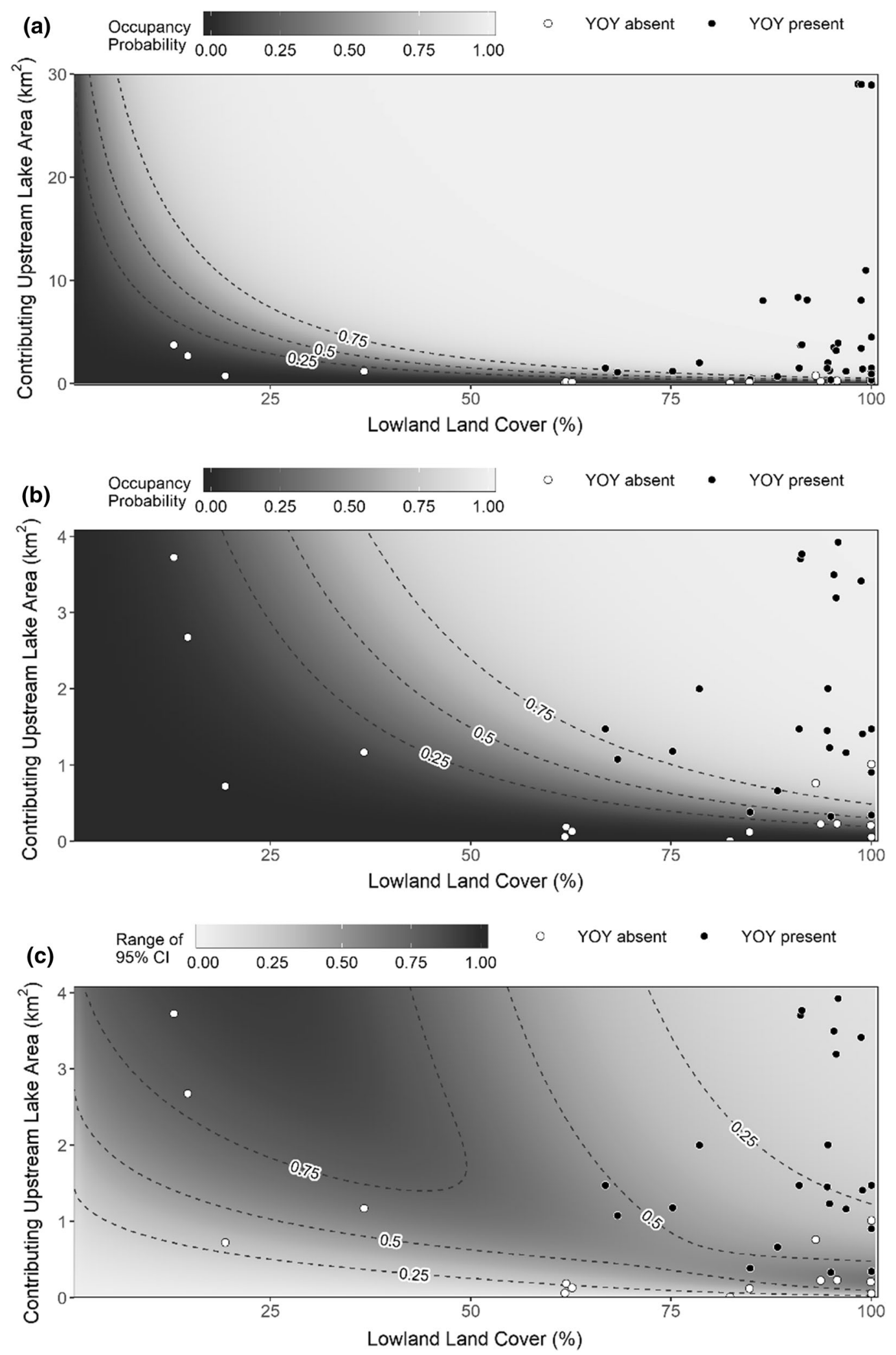
4 Fig. 5 Bivariate plots of contributing upstream lake area and \% lowland land cover showing a probability of occupancy of young of year Arctic grayling for the full range of stream conditions observed, b estimated occupancy of YOY for the range of contributing upstream lake area where probability of occupancy transitioned from low to high (note different $\mathrm{Y}$ axis compared to a), and $\mathbf{c}$ the range of $95 \%$ confidence intervals for the occupancy estimate, calculated as the upper limit minus the lower limit. The contour lines identify occupancy probabilities (a and b) and confidence interval ranges (c) of 0.25, 0.50, and 0.75 . Combined, these variables explained the occupancy results for 46 of the 48 streams included in the model. The $95 \%$ confidence interval ranges show that the model predicted both presence and absence with confidence (i.e., $\mathrm{CI}<0.25$ ), under certain combinations of upstream lake area and land cover. Data were collected near Baker Lake, Nunavut, Canada in 2019

greater depths or with greater disturbance (higher velocity). The interaction term suggests that detection probability remained high in deep water with low velocity, or in shallow water with high velocity. However, detection probability decreased rapidly in deep, high velocity water.

\section{Assessment of model fit}

\section{Occupancy}

Model fit was evaluated using independent presence/ absence data that were collected several years prior to the study, and from additional streams within the study area (C. Portt and Associates, 2015). Land classification and contributing upstream lake area were calculated for the seven streams in the test data set, and were used to estimate probability of occupancy. No Arctic grayling of any life stage were detected in the seven streams and the absence of YOY in these streams was well-predicted by the model (Fig. S4a); probability of occupancy was $<0.20$ for six streams, whereas probability of occupancy was 0.66 for one stream. The estimated occupancy probability of 0.66 for the one unoccupied stream was associated with a large 95\% CI (0.08-0.98; Fig. S4b).

\section{Detection}

A comparison of $\chi^{2}$ test statistics between observed and parametric bootstrapped data yielded a $\widehat{c}$ value of 3.4 , suggesting the model is overdispersed. Overdispersion can reflect non-independent observations (e.g., detection in replicate $\mathrm{B}$ is dependent on detection in replicate A) or structural inadequacies, such as unmodeled heterogeneity in detection. A model structure that included spatial dependency failed to converge (see above). We suggest that unmodeled heterogeneity in detection probability was due to relative differences in abundance of YOY among streams, which in turn affected detection probabilities. If abundance was not correlated with any detection covariates that were collected, then heterogeneity remains unmodeled. A comparison of the observation rate (number of YOY observed per minute) among replicates during presence/absence surveys at each stream suggests that detection efficiency is related to

Table 3 Summary of detection models for visual surveys of Arctic grayling young-of-year in Barrenland streams

\begin{tabular}{lllllll}
\hline Model & $\Delta$ AICc & $-2 l$ & $\omega$ & & \multicolumn{2}{l}{ Coefficient estimates $( \pm$ standard error) } \\
\cline { 5 - 7 } & & & & Depth & Velocity & Depth $\times$ velocity \\
\hline$p$ (Depth $\times$ velocity) & 0.00 & 158.74 & 0.43 & $-0.42(0.22)$ & $-0.32(0.22)$ & $-0.31(0.20)$ \\
$p$ (Depth + velocity) & 0.37 & 161.85 & 0.36 & $-0.42(0.22)$ & $-0.44(0.19)$ & - \\
$p$ (Velocity) & 2.75 & 166.86 & 0.11 & - & $-0.51(0.19)$ & - \\
$p($ Depth) & 3.02 & 167.13 & 0.09 & $-0.48(0.18)$ & - & - \\
$p(\cdot)$ & 7.68 & 174.28 & 0.01 & - & - & - \\
\hline
\end{tabular}

To allow for a direct comparison, the same model for occupancy probability was used for all candidate detection models

$\triangle \mathrm{AICc}$, difference in AICc value between a particular model compared to the top ranked model; $-2 l$, twice the negative loglikelihood value; $\omega$, AIC model weight

Occupancy probability was modeled as $\psi(\sqrt{\text { Lowland } \%}+\log ($ UpstreamLakeArea $))$ for all models, with the exception of the null, $\Psi(\cdot)$ 
abundance. Observation rate within a replicate (where YOY were detected) was lower in streams with imperfect detection, and decreased as detection efficiency decreased (Fig. S5); high observation rates (up to $7.33 \mathrm{YOY} /$ minute) occurred at streams with perfect detection, and low observation rates (as low as 0.13 YOY/minute) occurred at streams with imperfect detection. A higher observation rate is likely the result of an increased number of YOY within the stream, suggesting that relative differences in abundance among streams, which are unaccounted for in the model, led to higher than expected variance (i.e., overdispersion) (Royle \& Nichols, 2003). Since overdispersion was not attributed to non-independent observations, a correction to the AIC scores (QAIC) was not applied (as per MacKenzie et al., 2018).

\section{Discussion}

\section{Occupancy}

The suitability of Barrenland streams for YOY Arctic grayling was strongly influenced by the surrounding landscape. Two landscape-level variables, land classification (upland vs. lowland) and contributing upstream lake area, were better predictors of YOY grayling occupancy than any combination of the within-stream habitat variables that were collected. By considering how landscape-level variables affect stream habitat, particularly during the summer rearing period, critical habitat for YOY Arctic grayling in Barrenlands landscapes can be better understood and predicted. This will allow for more effective and efficient monitoring, mitigation, and conservation in this vast, remote, and understudied ecoregion.

Sixteen of 48 surveyed streams were unoccupied, and absence of Arctic grayling YOY in 10 of the unoccupied streams was explained by having fewer or smaller lakes upstream, providing less contribution to base flow. Headwater streams, and those that were located further upstream within a chain-lake system, had a lower probability of containing YOY Arctic grayling. Lakes are known to moderate and improve the reliability of source flow (Jones, 2010), and the degree to which an upstream catchment contributes to downstream flow is dependent on antecedent lake storage, rainfall, and evaporative losses (Baki et al., 2012; Baker et al., 2016). In a landscape where summer evaporation typically exceeds precipitation, an increase in the number and/or size of upstream lakes may increase the likelihood that streamflow and connectivity for migratory fishes will be sustained throughout the ice-free season. For YOY Arctic grayling, sustained flow is crucial, as habitat connectivity is required for migration to overwintering lakes prior to freeze-up (Jones et al., 2003a; Heim et al., 2016). The importance of stream connectivity for Arctic grayling distribution has also been noted in the Arctic Coastal Plains of Alaska, where a sustained stream connection during the open water season (rather than an ephemeral connection) is a strong predictor of Arctic grayling occupancy in lakes (Haynes et al., 2014; Laske et al., 2016). In the Barrenlands, Arctic grayling use of chain-lake habitat, particularly lakes with inconsistent connectivity, warrants investigation and may help to further explain YOY stream occupancy.

Further evidence of the influence of upstream lakes on stream flow was demonstrated by the significant and positive correlation between contributing upstream lake area and stream discharge (Pearson's $r$ of 0.87 ). This suggests that upstream lakes contribute to maintaining baseflow in Barrenland streams in the study area throughout the open water season, and among years. Unoccupied streams with low contributing upstream lake area were likely unsuitable for YOY Arctic grayling due to insufficient discharge. Contributing upstream lake area may, in fact, be used as a reliable surrogate for discharge in Barrenlands landscapes, and allow for comparisons among streams when discharge measurements cannot be taken within a short temporal window. Stream discharge measurements for this study were collected under a wide range of weather conditions, including periods of dry weather followed by heavy rain events. These events, including one when $48 \mathrm{~mm}$ of rain fell in less than $72 \mathrm{~h}$, influenced discharge and confounded comparisons among streams (Fig. S3). Incorporating contributing upstream lake area into models in place of discharge allowed for a comparison among streams that was more representative of longer-term hydrological conditions. Barrenland streams with reliable flow during the open water season, or a predictable, sustained discharge across years are more likely to be used by Arctic grayling (see Heim et al., 2019b). Given that Arctic grayling show strong site fidelity to spawning and summer feeding sites (Northcote, 1995; 
Deegan et al., 1999; Buzby \& Deegan, 2000), the absence of YOY in streams may be a result of an unpredictable base flow across years, which can be assessed more accurately in the Barrenlands by calculating upstream lake area rather than by collecting a single discharge measurement in a given year.

Streams with small contributing upstream lake area (and correlated lower discharge) had additional habitat features that were likely unsuitable for YOY Arctic grayling. Many of these small streams were dominated by organic substrates and instream vegetation, likely because there was insufficient flow to mobilize even fine substrates. The six streams with highest $\%$ organic substrate were a subset of the 10 streams where YOY absence was explained by low contributing upstream lake area. Arctic grayling prefer gravel for spawning (Stewart et al., 2007). High relative \% organic material within streams that have small upstream lake area and low discharge may be unsuitable for spawning adults, leading to absence of YOY. Organic substrate was also highly correlated with several stream temperature metrics. Streams dominated by organic substrate had less stable temperature profiles, as daily temperature fluctuated up to $8^{\circ} \mathrm{C}$, and maximum temperatures sometimes exceeded $20^{\circ} \mathrm{C}$. This is likely because dark organic substrate absorbs more solar energy relative to the lighter coloured inorganic substrates. Data on the upper range of stream temperature used by YOY Arctic grayling is lacking (Stewart et al., 2007), although the thermal tolerance of YOY grayling has been found to exceed $24^{\circ} \mathrm{C}$ (LaPerriere \& Carlson, 1973). Deegan et al. (1999) and Luecke \& MacKinnon (2008) found that growth of YOY Arctic grayling in Alaskan streams was positively correlated with water temperature; however, the effects of large, daily water temperature fluctuations on YOY habitat suitability are unknown, and requires further study.

Although low contributing upstream lake area explained absence of YOY in 10 of 16 unoccupied streams, YOY Arctic grayling were absent in six streams that appeared to have sufficient streamflow. Four of six of these absences were explained by land classification. Most streams included in this study were situated within lowland-dominated landscapes; however, four study streams where YOY were absent had upland land cover that exceeded 50\%. Since Barrenland streams are colluvial, upland streams are dominated by unconfined boulder channels with large interstitial spaces (Fig. S6). Reductions in flow and loss of surface connectivity in Barrenland streams over the course of the summer (Jones et al., 2003a) may be especially prevalent in upland landscapes, where interstitial spaces around boulders and unconfined channel structures promote subsurface flow at low discharges. Indeed, this was directly observed at several upland study streams in late summer (Fig. S6), and suggests that a larger contributing upstream lake area is required to maintain connectivity throughout summer for streams in upland-dominated landscapes. Power \& Barton (1987) describe stream conditions in Ungava Bay, Quebec, where diffuse and subsurface flow through boulder-dominated streams prevented upstream migration of Arctic char, particularly in dry years. Reduced stream flow in the fall as a result of climate change is expected to affect connectivity of Arctic aquatic habitats, with particularly large effects on migratory fishes (Reist et al., 2006; Betts \& Kane, 2015).

Authors of previous studies conducted in the Barrenlands found that several habitat variables influenced the presence of YOY Arctic grayling, including water depth, water velocity, discharge, substrate, slope, detritus, and instream and overhanging vegetation (Jones \& Tonn, 2004; Artym, 2016; Baker et al., 2017). Of these variables, discharge, slope, and substrate (expressed as \% inorganic) provided some explanation of stream occupancy in our study. We sampled a wider range of stream conditions than previous studies, and it is possible that instream variables (e.g., water depth, water velocity) are less important when predicting occupancy over a larger spatial scale or more diverse landscape. Our measurements of instream habitat variables under sometimes extreme conditions, such as during heavy rain events, likely confounded any relationships with occupancy, and precluded meaningful comparisons of results among studies. We conclude that connectivity, inferred through the variables of contributing upstream lake area and land cover, were the primary driver of YOY occupancy in our study. Connectivity has been identified as an important factor for explaining YOY presence in other studies (Jones \& Tonn, 2004; Artym, 2016; Baker et al., 2017), as habitat variables such as discharge, slope, substrate, water depth, and water velocity often reflect, or are related to, stream connectivity. 
Detection

Detection efficiency was high overall; however, increases in average water depth and velocity reduced the probability that YOY would be detected. A general trend of decreasing detection efficiency with increasing depth during visual surveys has been observed in previous studies of YOY Arctic grayling (Artym, 2016) and smallmouth bass [Micropterus dolomieu (Lacepéde, 1802)] YOY (Brewer \& Ellersieck, 2011). While neither study found a statistically significant relationship between velocity and probability of detection, average site velocities were low $(0.085 \mathrm{~m} /$ $\mathrm{s}$ for Artym (2016) and $0.054 \mathrm{~m} / \mathrm{s}$ for Brewer \& Ellersieck (2011)) relative to velocities measured in this study $(0.24 \mathrm{~m} / \mathrm{s})$.

Overdispersion ( $\widehat{c}$ of 3.4 ) was observed in the model of detection probability. Unmodeled heterogeneity in detection probability was the suspected cause of overdispersion (i.e., there was a factor influencing the detection probability that was not accounted for in the model), and was likely due to variation in abundance of YOY among streams. The size of the local population at each replicate impacts detection probability, and variation in abundance can be the leading cause of heterogeneity in detection probabilities in occupancy studies (Royle \& Nichols, 2003). For juvenile bull tout [Salvelinus confluentus (Suckley, 1859)] occupying mountain streams in the Northwest Territories, detection probability is high ( $p=0.78)$ in core habitat areas, but is greatly reduced ( $p=0.48)$ in fringe habitats near distributional boundaries (Mochnacz et al., 2021), where abundance is likely lower. Most occupied streams surveyed in this study had perfect detection (62.5\%), and are likely core habitat areas for YOY grayling. What constitutes fringe habitat for YOY Arctic graying in Barrenland streams is poorly understood. While collection of additional stream variables, such as food availability (see Jones et al., 2003b), may help to identify fringe habitat and account for the unmodeled heterogeneity in detection, it is also likely that fringe habitat for YOY rearing in streams is correlated with the distributional patterns and habitat requirements of adults. Developing a broader understanding of habitat use of all life stages of Arctic grayling in the Barrenlands may help to identify more cryptic variables that are related to core and fringe stream habitat for YOY.

\section{Conclusion}

Critical knowledge gaps regarding ecology and life history of northern populations of Arctic grayling preclude accurate or precise predictions regarding potential impacts of human-induced stressors. This is particularly true for regions where habitat use is poorly understood, such as in Arctic Barrenland landscapes. The Barrenlands are dominated by networks of seasonally connected lakes and streams that allow adfluvial populations of Arctic grayling to migrate, spawn, and rear. Results of our study indicate that suitability of Barrenland stream habitat for YOY Arctic grayling is limited by connectivity. In the Barrenlands, the importance of headwater lakes in ensuring the permanence of stream connections (persistence of flow) is evident, given the strong correlation between contributing upstream surface area and stream discharge. In lowland regions, stream connectivity within chain-lake systems is well defined, and even a small contributing upstream lake area can promote sustained flow through the open water season. For upland regions, a larger contribution from upstream lakes is required to maintain connectivity, and thus there are fewer suitable streams within this landscape for YOY to rear. Through occupancy modeling we identified that surrogates of connectivity (i.e., contributing upstream lake area and landcover), which can be calculated using publicly available data (e.g., Campbell et al., 2012; Natural Resources Canada, 2016), adequately predict YOY Arctic grayling stream use in the Barrenlands. Use of this model as a predictive tool could lessen the considerable financial and logistical constraints of conducting remote Arctic fieldwork and facilitate more focused field programs to inform conservation and mitigation plans.

Acknowledgements The authors would like to thank Bronte McPhedran, Cam Portt, and Monica Gromala for assistance with field data collection. Additional planning, logistics, and field support were provided by Ryan VanEngen, Leilan Baxter, Robin Allard, Martin Archambault, Tom Thomson, and many others in the Meadowbank and Amaruq Environment Departments. Mark Servos, Paul Craig, and two anonymous reviewers provided valuable comments on earlier versions of this manuscript. Funding and in-kind support was provided by Agnico Eagle Mines Limited. Additional funding was provided by the Polar Knowledge Canada Northern Scientific Training Program to J. Ellenor. This study was performed under Nunavut Research Institute Scientific Research License 02023 18N-M 
and 03013 19R-M and under Kivalliq Inuit Association Certificate of Exemption KVX18N04.

Author contributions Conceptualization: HKS; Methodology: JRE, HKS, PAC; Formal analysis and investigation: JRE; Writing — original draft preparation: JRE; Writing — review and editing: HKS, PAC; Funding acquisition: HKS; Supervision: HKS

Funding Funding and in-kind support was provided by Agnico Eagle Mines Limited. Additional funding was provided by the Northern Scientific Training Program to J. Ellenor.

Data availability Data from this study are available from the corresponding author upon request.

Code availability Code from this study are available from the corresponding author upon request.

\section{Declarations}

Conflict of interest No conflict of interest.

Ethical approval This study was performed under Nunavut Research Institute Scientific Research Licence 0202318 N-M and 03013 19R-M and under Kivalliq Inuit Association Certificate of Exemption KVX18N04.

Consent for publication Figure 2 was modified, with permission from Campbell et al., 2012.

Open Access This article is licensed under a Creative Commons Attribution 4.0 International License, which permits use, sharing, adaptation, distribution and reproduction in any medium or format, as long as you give appropriate credit to the original author(s) and the source, provide a link to the Creative Commons licence, and indicate if changes were made. The images or other third party material in this article are included in the article's Creative Commons licence, unless indicated otherwise in a credit line to the material. If material is not included in the article's Creative Commons licence and your intended use is not permitted by statutory regulation or exceeds the permitted use, you will need to obtain permission directly from the copyright holder. To view a copy of this licence, visit http://creativecommons.org/licenses/by/4.0/.

\section{References}

Anderson, D. R., 2008. Model Based Inference in the Life Sciences: A Primer on Evidence, Springer, New York, London:

Artym, K., 2016. Determining the habitat occupancy of young of year Arctic Grayling (Thymallus arcticus) in sub-Arctic tundra streams while accounting for imperfect detection. Master's Thesis, University of Waterloo.
Bain, M. B., J. T. Finn \& H. E. Booke, 1985. Quantifying stream substrate for habitat analysis studies. North American Journal of Fisheries Management 5: 499-506.

Baker, L. F., K. J. Artym \& H. K. Swanson, 2017. Optimal sampling methods for modelling the occupancy of Arctic grayling (Thymallus arcticus) in the Canadian Barrenlands. Canadian Journal of Fisheries and Aquatic Sciences 74: 1564-1574.

Baker, M. A., C. D. Arp, K. J. Goodman, A. M. Marcarelli, \& W. A. Wurtsbaugh, 2016. Stream-lake interaction: understanding coupled hydro-ecologial systems In Jones, J. B., \& E. H. Stanley (eds), Stream Ecosystems in a Changing Environment. Academic Press, Cambridge.

Baki, A. B. M., D. Z. Zhu, M. F. Hulsman, B. D. Lunn \& W. M. Tonn, 2012. The hydrological characteristics of a stream within an integrated framework of lake-stream connectivity in the Lac de Gras Watershed, Northwest Territories, Canada. Canadian Journal of Civil Engineering 39: 279-292.

Betts, E. D. \& D. L. Kane, 2015. Linking North Slope of Alaska climate, hydrology, and fish migration. Hydrology Research 46: 578-590.

Birtwell, I. K., G. F. Hartman, B. Anderson, D. J. McLeay, \& J. G. Malick, 1984. A brief investigation of Arctic grayling (Thymallus arcticus) and aquatic invertebrates in the Minto Creek drainage, Mayo, Yukon Territory: An area subjected to placer mining. Canadian Technical Report of Fisheries and Aquatic Sciences: 57.

Brewer, S. K. \& M. R. Ellersieck, 2011. Evaluating two observational sampling techniques for determining the distribution and detection probability of age-0 Smallmouth Bass in clear, warmwater streams. North American Journal of Fisheries Management 31: 894-904.

Buzby, K. M. \& L. A. Deegan, 2000. Inter-annual fidelity to summer feeding sites in Arctic Grayling. Environmental Biology of Fishes 59: 319-327.

C. Portt and Associates, 2015. Amaruq Exploration Access Road Aquatic Baseline Report 2015 Agnico Eagle Mines Ltd.-Meadowbank Division. C. Portt and Associates, Guelph: 89.

C. Portt and Associates, 2018. Whale Tail Pit 2014-2016 Fish and Fish Habitat Field Investigations: Agnico Eagle Mines Ltd.-Meadowbank Division. C. Portt and Associates, Guelph: 155 .

Campbell, M. W., J. G. Shaw, \& C. A. Blyth, 2012. Kivalliq ecological land classification map atlas: A wildlife perspective. Government of Nunavut, Department of Environment, Nunavut: 274.

Carl, L. M., D. Walty \& D. M. Rimmer, 1992. Demography of spawning grayling (Thymallus arcticus) in the Beaverlodge River, Alberta. Hydrobiologia 243: 237-247.

Courtice, G., A. B. M. Baki, D. Z. Zhu, C. Cahill \& W. M. Tonn, 2014. Stream modifications to enhance system connectivity for fish habitat compensation: a case study in the Barrenlands region of Canada. Canadian Journal of Civil Engineering 41: 650-659.

Cumberland Resources Ltd., 2005. Meadowbank Gold Project Habitat and Fisheries Assessment: All-Weather Road. Cumberland Resources Ltd., Cumberland: 142.

Deegan, L. A., H. E. Golden, C. J. Harvey \& B. J. Peterson, 1999. Influence of environmental variability on the growth 
of age- 0 and adult Arctic Grayling. Transactions of the American Fisheries Society 128: 1163-1175.

Dorava, J. M. \& A. M. Milner, 2000. Role of lake regulation on glacier-fed rivers in enhancing salmon productivity: the cook inlet watershed, South-Central Alaska, USA. Hydrological Processes 14: 3149-3159.

Driedger, K. L. F., L. P. Weber, I. K. Birtwell \& D. M. Janz, 2011. Growth, condition and energy stores of Arctic grayling fry inhabiting natural and artificial constructed Arctic tundra streams. Limnologica 41: 63-69.

Environment and Climate Change Canada, 2018. Canadian Climate Normals. 1981-2010 Station Data-Baker Lake A. https://climate.weather.gc.ca/climate_normals/index_e. html.

Google Earth, 2019a. Landsat/Copernicus Imagery near Baker Lake, Nunavut. Google.

Google Earth, 2019b. Maxar Technologies Imagery near Baker Lake, Nunavut. Google.

Google Earth, 2019c. CNES/Airbus Imagery near Baker Lake, Nunavut. Google.

Haugen, T. O. \& L. A. Vollestad, 2000. Population differences in early life-history traits in grayling. Journal of Evolutionary Biology 13: 897-905.

Haynes, T. B., A. E. Rosenberger, M. S. Lindberg, M. Whitman \& J. A. Schmutz, 2014. Patterns of lake occupancy by fish indicate different adaptations to life in a harsh Arctic environment. Freshwater Biology 59: 1884-1896.

Heim, K. C., C. D. Arp, M. S. Whitman \& M. S. Wipfli, 2019a. The complementary role of lentic and lotic habitats for Arctic Grayling in a complex stream-lake network in Arctic Alaska. Ecology of Freshwater Fish 28: 209-221.

Heim, K. C., T. E. McMahon, L. Calle, M. S. Wipfli \& J. A. Falke, 2019b. A general model of temporary aquatic habitat use: Water phenology as a life history filter. Fish and Fisheries 20: 802-816.

Heim, K. C., M. S. Wipfli, M. S. Whitman, C. D. Arp, J. Adams \& J. A. Falke, 2016. Seasonal cues of Arctic Grayling movement in a small Arctic stream: the importance of surface water connectivity. Environmental Biology of Fishes 99: 49-65.

Hershey, A. E., S. Beaty, K. Fortino, M. Keyse, P. P. Mou, W. J. O'Brien, A. J. Ulseth, G. A. Gettel, P. W. Lienesch, C. Luecke, M. E. Mcdonald, C. H. Mayer, M. C. Miller, C. Richards, J. A. Schuldt \& S. C. Whalen, 2006. Effect of landscape factors on fish distribution in arctic Alaskan lakes. Freshwater Biology 51: 39-55.

Hershey, A. E., G. Gettel, M. Mcdonald, M. Miller, W. J. O'Brien, J. Pastor, C. Richards \& J. A. Schuldt, 1999. A geomorphic-trophic model for landscape control of Arctic lake food webs. BioScience 49: 887-897.

Jones, B. M., C. D. Arp, K. M. Hinkel, R. A. Beck, J. A. Schmutz $\&$ B. Winston, 2009. Arctic lake physical processes and regimes with implications for winter water availability and management in the National Petroleum Reserve Alaska. Environmental Management 43: 1071-1084.

Jones, N. E., 2010. Incorporating lakes within the river discontinuum: longitudinal changes in ecological characteristics in stream-lake networks. Canadian Journal of Fisheries and Aquatic Sciences 67: 1350-1362.

Jones, N. E., G. J. Scrimgeour \& W. M. Tonn, 2017. Lessons learned from an industry, government and university collaboration to restore stream habitats and mitigate effects. Environmental Management 59: 1-9.

Jones, N. E. \& W. M. Tonn, 2004. Resource selection functions for age-0 Arctic Grayling (Thymallus arcticus) and their application to stream habitat compensation. Canadian Journal of Fisheries and Aquatic Sciences 61: 1736-1746.

Jones, N. E., W. M. Tonn, G. J. Scrimgeour \& C. Katopodis, 2003a. Ecological Characteristics of Streams in The Barrenlands Near Lac de Gras, N.W.T. Canada. ARCTIC 56: 249-261.

Jones, N. E., W. M. Tonn, G. J. Scrimgeour \& C. Katopodis, 2003b. Productive capacity of an artificial stream in the Canadian Arctic: assessing the effectiveness of fish habitat compensation. Canadian Journal of Fisheries and Aquatic Sciences 60: 849-863.

Kitikmeot Inuit Association, 2006. Naonalyaotit Traditional Knowledge Project. Volume II Fish and Wildlife. Report 1 Ekalok (fish) and Fishing, Cambridge Bay and Kugluktuk NU.

Lane, R. J., 1999. The Water Survey of Canada Hydrometric Technician Career Development Program: Lesson Package No, 10.1-Principles of Discharge Measurements. Environment Canada, Toronto

LaPerriere, J. D. \& R. F. Carlson, 1973. Thermal Tolerances of Interior Alaskan Arctic Grayling (Thymallus arcticus), University of Alaska, Fairbanks, Alaska, Institute of Water Resources:

Laske, S. M., T. B. Haynes, A. E. Rosenberger, J. C. Koch, M. S. Wipfli, M. Whitman \& C. E. Zimmerman, 2016. Surface water connectivity drives richness and composition of Arctic lake fish assemblages. Freshwater Biology 61: 1090-1104.

Lin Pederson, T., 2020. patchwork: The Composer of Plots. Data Imaginist, https://patchwork.data-imaginist.com/.

Lüdecke, D., M. S. Ben-Shachar, P. Waggoner, \& D. Makowski, 2020. See: an R package for visualizing statistical models. Journal of Open Source Software. https://doi.org/10. 21105/joss.03393.

Luecke, C. \& P. MacKinnon, 2008. Landscape effects on growth of age-0 Arctic Grayling in Tundra Streams. Transactions of the American Fisheries Society 137: 236-243.

MacKenzie, D. I. \& L. L. Bailey, 2004. Assessing the fit of siteoccupancy models. Journal of Agricultural, Biological, and Environmental Statistics 9: 300-318.

MacKenzie, D. I., \& J. E. Hines, 2019. RPresence: R interface for program PRESENCE. https://www.mbr-pwrc.usgs. gov/software/presence.shtml.

MacKenzie, D. I., J. D. Nichols, J. A. Royle, K. H. Pollock, L. L. Bailey \& J. E. Hines, 2018. Occupancy Estimation and Modeling: Inferring Patterns and Dynamics of Species Occurrence, Elseiver, London

McLeay, D. J., I. K. Birtwell, G. F. Hartman \& G. L. Ennis, 1987. Responses of Arctic Grayling (Thymallus arcticus) to acute and prolonged exposure to Yukon placer mining sediment. Canadian Journal of Fisheries and Aquatic Sciences 44: 658-673.

Mochnacz, N. J., D. I. MacKenzie, N. Koper, M. F. Docker \& D. J. Isaak, 2021. Fringe effects: detecting bull trout (Salvelinus confluentus) at distributional boundaries in a montane watershed. Canadian Journal of Fisheries and Aquatic Sciences 78: 1030-1044. 
Natural Resources Canada, 2016. National hydro networkNHN_GeoBase series. https://open.canada.ca/data/en/ dataset/a4b190fe-e090-4e6d-881e-b87956c07977.

Northcote, T. G., 1995. Comparative biology and management of Arctic and European grayling (Salmonidae, Thymallus). Reviews in Fish Biology and Fisheries 5: 141-194.

Pépino, M., M. A. Rodríguez \& P. Magnan, 2017. Incorporating lakes in stream fish habitat models: are we missing a key landscape attribute? Canadian Journal of Fisheries and Aquatic Sciences 74: 629-635.

Phibbs, J., B. McLaren, \& T. Hnatiuk, 2011. Lupine gold mine environmental effects monitoring-cycle 3 interpretative report. AECOM, Edmonton, AB.

Power, G. \& D. R. Barton, 1987. Some effects of physiographic and biotic factors on the distribution of anadromous Arctic Char (Salvelinus alpinus) in Ungava Bay, Canada. ARCTIC 40: 198-203.

QGIS Development Team, 2020. QGIS Geographic Information System. Open Source Geospatial Foundation Project.

R Core Team, 2019. R: A Language and Environment for Statistical Computing. R Foundation for Statistical Computing, Vienna, Austria.

Read, C. J., \& M. M. Roberge, 1984. Enumeration and biological data on Arctic Grayling, Thymallus arcticus, Kakisa River, N.W.T. Canadian Data Report of Fisheries and Aquatic Sciences: 750: iV+15 p.

Reist, J. D., F. J. Wrona, T. D. Prowse, M. Power, J. B. Dempson, R. J. Beamish, J. R. King, T. J. Carmichael, \& C. D. Sawatzky, 2006. General effects of climate change on Arctic fishes and fish populations. AMBIO: A Journal of the Human Environment 35: 370-380.
Reynolds, J. B., R. C. Simmons \& A. R. Burkholder, 1989. Effects of placer mining discharge on health and food of Arctic Grayling. Journal of the American Water Resources Association 25: 625-635.

Royle, J. A. \& J. D. Nichols, 2003. Estimating abundance from repeated presence-absence data or point counts. Ecology 84: 777-790.

Scott, W. B., \& E. J. Crossman, 1973. Freshwater fishes of Canada. Fisheries Research Board of Canada, Ottawa, Ontario.

Stewart, D. B., N. J. Mochnacz, J. D. Reist, T. J. Carmichael, \& C. D. Sawatzky, 2007. Fish life history and habitat use in the Northwest Territories: Arctic Grayling (Thymallus arcticus). Fisheries and Oceans Canada, Winnipeg, MB: 63.

Veldhoen, N., J. E. Beckerton, J. Mackenzie-Grieve, M. R. Stevenson, R. L. Truelson \& C. C. Helbing, 2014. Development of a non-lethal method for evaluating transcriptomic endpoints in Arctic Grayling (Thymallus arcticus). Ecotoxicology and Environmental Safety 105: 43-50.

Wickham, H., 2016. ggplot2: Elegant Graphics for Data Analysis. Springer-Verlag New York, https://ggplot2.tidyverse. org.

Woo, M. \& C. Mielko, 2007. An integrated framework of lakestream connectivity for a semi-arid, subarctic environment. Hydrological Processes 21: 2668-2674.

Publisher's Note Springer Nature remains neutral with regard to jurisdictional claims in published maps and institutional affiliations. 